\title{
American Association for Thoracic Surgery: Maintaining the mission during the coronavirus disease 2019 (COVID-19) pandemic
}

\author{
Marc R. Moon, MD, ${ }^{a}$ David R. Jones, MD, ${ }^{b}$ \\ David H. Adams, MD, ${ }^{c}$ and Vaughn A. Starnes, MD $^{\mathrm{d}}$
}

These are unprecedented times-or are they? For our generation of cardiothoracic surgeons, the answer is clear. We have never experienced anything this disruptive in our lives. But for the American Association for Thoracic Surgery (AATS), maybe not so much. This is not the first time the AATS Annual Meeting has been disrupted by world events. In 1942, 1943, and 1945, the Annual Meeting was either cancelled or postponed during the world's second great conflict. Going back more than 100 years, it is also important to note that the AATS was actually founded during times of great strife in 1917 during the First World War.

The founder of the AATS was Dr Willy Meyer, a dedicated thoracic surgeon at the German Hospital (Lenox Hill) in New York. Dr Meyer emigrated from Germany in the late 1800s after serving as an army surgeon during the aftermath of the Franco-Prussian War. ${ }^{1}$ In 1917, Dr Meyer founded the AATS in the midst of the "Great War," a conflict that was destined to become a war of totality. Never had a war covered so large a part of the earth. A century later, you would hardly consider those times to be favorable for the founding and growth of an organization that was not directly involved in the war effort. Despite the many obstacles, Dr Meyer's group felt strongly that trauma and infectious diseases of the chest would play a major role during the war and that they should not let the progress they had made to this point fade away. ${ }^{2}$ Remarkably similar to current-day conditions facing the 100th Annual Meeting, the Inaugural AATS Meeting in 1918 took place June 10 in Chicago during the first wave of the world's most deadly pandemic-H1N1 influenza A, which took the life of an estimated 50 million worldwide. In contrast to today,

\footnotetext{
From the a Division of Cardiothoracic Surgery, Washington University School of Medicine, St Louis, Mo; ${ }^{\text {b}}$ Thoracic Service, Department of Surgery, Memorial Sloan Kettering Cancer Center, New York, NY; ${ }^{\mathrm{c} D e p a r t m e n t}$ of Cardiovascular Surgery, Icahn School of Medicine at Mount Sinai, New York, NY; and ${ }^{\mathrm{d}}$ Department of Surgery, Keck School of Medicine of USC, Los Angeles, Calif.

Received for publication May 11, 2020; revisions received May 11, 2020; accepted for publication May 12, 2020; available ahead of print May 16, 2020.

Address for reprints: Marc R. Moon, MD, Washington University School of Medicine, 4566 Scott Ave, Campus Box 8234, St Louis, MO 63110 (E-mail: moonm@wustl.edu).

J Thorac Cardiovasc Surg 2020;160:737-9

$0022-5223 / \$ 36.00$

Copyright (C) 2020 by The American Association for Thoracic Surgery

https://doi.org/10.1016/j.jtcvs.2020.05.022
}

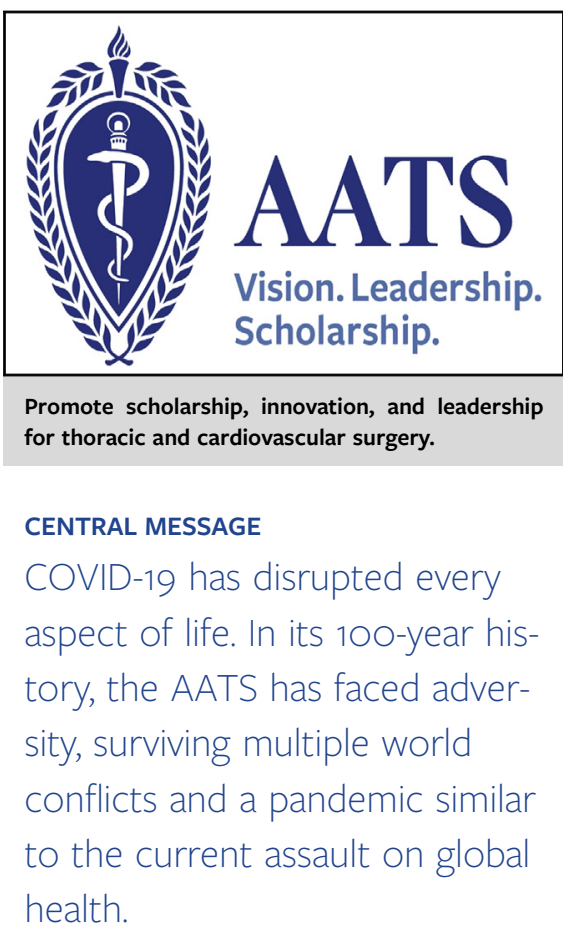

however, the world was slow to identify the importance of isolation, quarantine, good personal hygiene, and limitations to public gatherings (Figure 1).

The 1918 influenza pandemic was deadly and disruptive, but it did not change the world forever, and neither will coronavirus disease 2019 (COVID-19). We will conquer this novel disease, but in the meantime, changes to protect patients, health care workers, and the community at large are paramount. As the first cases of suspected local transmission in the United States surfaced toward the beginning of March 2020, AATS leadership began to explore options for the Annual Meeting scheduled just 8 weeks forward in New York City, an evolving hotspot for viral spread. It was becoming increasingly clear that our international colleagues were not going to be able to attend the Annual Meeting due to worldwide travel restrictions. Without the international cardiothoracic community in attendance, the Annual Meeting would not be the same. 


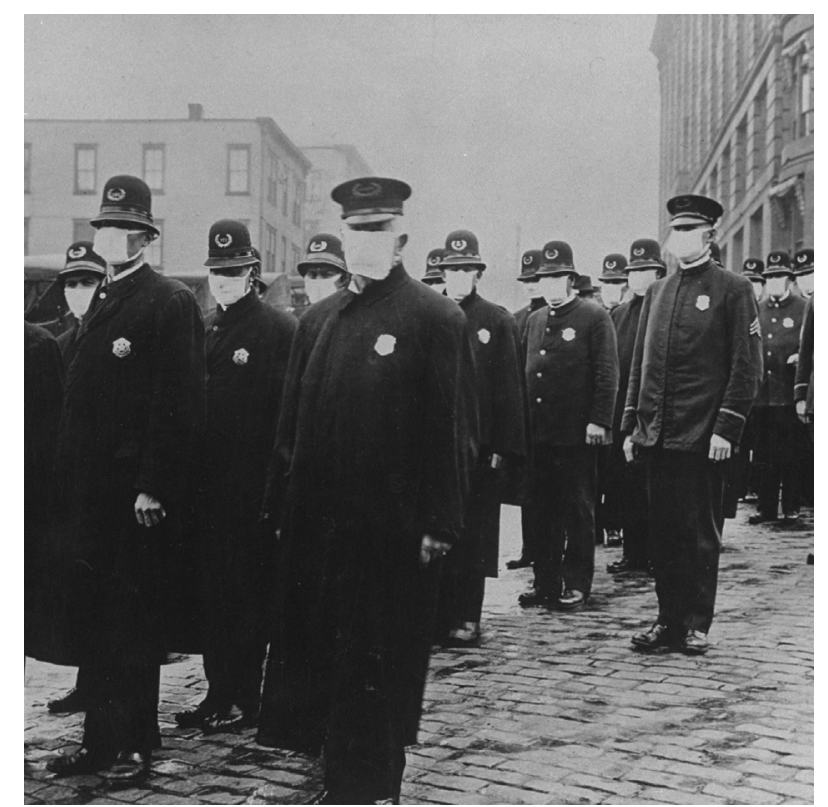

FIGURE 1. Police officers wearing protective masks made by the Red Cross shortly after the 1st AATS Annual Meeting in 1918 as the influenza pandemic raged (National Archives).

The AATS, since its inception, has been an international organization. Although the first name of the Association is "American," the first Officers were all born outside North America: President Dr Samuel Meltzer from Russia, VicePresident Dr Willy Meyer from Germany, and SecretaryTreasurer Dr Nathan Green from Ceylon (Sri Lanka). ${ }^{3}$ The first AATS member who practiced outside North America was Georges Dehelly of LeHavre, France, who was elected to membership at the 1st Annual Meeting in 1918. In addition, the first paper published in the Journal of Thoracic Surgery in 1931 (which went on to become the Journal of Thoracic and Cardiovascular Surgery ${ }^{4}$ ) was from Peiping Union Medical College in China. ${ }^{5}$ The AATS, for history's sake, will continue with its century-long name, but its spirit has become increasingly international, focused on bidirectional knowledge sharing across the globe. We realize there are many surgeons around the world who do not have the resources to attend the AATS Annual Meeting each spring in person. As such, we have made it part of our mission moving forward to increase our global outreach for education and to promote excellence in clinical care.

The 100th Annual Meeting saw a record number of abstract submissions at $1297-18 \%$ greater than the previous high of 1098 submitted for the 99th Annual Meeting in Toronto in 2019. More than $50 \%$ of abstracts were submitted from international centers, consistent with the AATS tradition of nearly $50 \%$ attendees residing outside North America. The 2020 meeting was to be represented by more than 70 countries from around the world, not far behind the 92 nation total that participated in the most recent Olympics
Games in Pyeongchang, South Korea. Cancellation of the meeting was considered, but 12 months seemed too long to share some of the important novel reports scheduled for presentation.

Historically, the Annual Meeting would also account for the majority of the AATS annual budget. Although the AATS has expanded its reach beyond the Annual Meeting, it still accounts for nearly $50 \%$ of the budget and revenue sources used to support the AATS mission to "promote scholarship, innovation, and leadership for thoracic and cardiovascular surgery." Fiscal responsibility became paramount while maintaining funding sources for the mission, including research grants, government relations, clinical care improvement initiatives, publications, international educational and clinical care outreach programs, and the distribution of scholarly knowledge. The 100th Annual Meeting Program Committee selected to follow the lead of the American College of Cardiology and modified the program to a virtual format. AATS CEO/Executive Director Cindy VerColen and her Meetings Team of Greg Zaralides, Michelle Cormier, and Melissa Binette worked diligently to rapidly develop the virtual meeting platform in which to hold the meeting.

\section{AATS 100TH ANNUAL MEETING: A VIRTUAL LEARNING EXPERIENCE, MAY 22-23, 2020}

The intent was to provide cardiothoracic surgery professionals and other interested parties around the world with complimentary access to some of the most exciting research, education, and science in the field without having to travel for a face-to-face interchange. The AATS Virtual Meeting Learning Experience, aptly entitled "Building the Next Century," is free to everyone. ${ }^{6}$ There is no cost and no preregistration required to attend. In addition, a Virtual Expo highlights new product innovations, technologies, and therapies in cardiothoracic surgery. All live content is available immediately after it airs live-on-demand, making available 26.5 AMA PRA Category 1 CME credits.

For logistical reasons, a reduction in the originally planned number of educational sessions was required. The 2020 Program Planning committee followed the format introduced at the 99th Annual Meeting in Toronto and slated more than 100 breakout sessions with 314 abstracts, 441 invited speakers, and 262 discussants. Although we would have liked to include the majority of this scholarly work, the mandate of the Virtual Program was to include the "best of the best" that would have the widest interest globally. Novel clinical and basic science research was favored over didactic presentations. The Virtual Program included 18 sessions, 60 abstracts, 7 invited speakers, and 70 discussants. In total, including moderators and panelists, more than 190 AATS members and nonmembers participated during the meeting. 
The 2020 Virtual 100th AATS Annual Meeting is available across the globe at no cost, thanks to our generous industry partners, including Premier Platinum Sponsors: Abbott, AtriCure, Edwards Lifesciences, and Medtronic, and our Platinum Sponsor Intuitive, joined by many others as identified on the AATS Virtual Meeting Expo. ${ }^{7}$ Their collective commitment with the AATS to this educational experience for the Global Cardiothoracic Community is truly appreciated by us all. The meeting begins with Tim Gardner's (82th AATS President) Legacy Lecture, "Proud Past, Limitless Future." The meeting culminates with Alec Patterson (90th AATS President) giving the David J. Sugarbaker Memorial Lecture: "The Road to Excellence" and Vaughn Starnes' 100th Presidential Address: "Thoracic Surgical Education in a Changing Paradigm." Please visit the Virtual Meeting Web site ${ }^{6}$ and our sponsors Expo ${ }^{7}$ as they become available to thank our generous contributors by exploring the educational and informational links that are easily accessed.

The AATS Virtual 100th Annual Meeting was born out of necessity but will unlikely represent a "one-anddone" phenomenon. AATS leadership is modeling future subspecialty virtual meetings on highly focused topics. The AATS Education Committees are currently developing plans for a monthly webinar platform to share the most important latest publications from the Journal of Thoracic and Cardiovascular Surgery and its other AATS partner journals. The AATS Online Committee is fine-tuning the Web site to facilitate information interchange in an on-demand manner. In addition, plans are underway to provide a virtual experience for the 101st Annual Meeting in Seattle for our global cardiothoracic community partners who may not have the resources at hand to attend the meeting in person. We would like to thank everyone for making the Virtual AATS 100th Annual Meeting a reality and for continuing to support the efforts of the Association to address its mission.
We look forward to seeing you all in New York City April 29-30, 2021, for the AATS Mitral Conclave and in Seattle May 1-4, 2021, for the AATS 101st Annual Meeting, which will include the rescheduled AATS Aortic Symposium, as we continue to plan for the second century of the American Association for Thoracic Surgery.

\section{Conflict of Interest Statement}

Dr Moon is a consultant/advisory board member for Medtronic. Dr Jones serves as a senior medical advisor for Diffusion Pharmaceuticals and a consultant for Merck and AstraZeneca. The Icahn School of Medicine at Mount Sinai receives royalty payments from Edwards Lifesciences and Medtronic for intellectual property related to Dr Adams' involvement in the development of 2 mitral valve repair rings and 1 tricuspid valve repair ring. Dr Adams is the $\mathrm{Na}-$ tional Co-Principal Investigator of the CoreValve United States Pivotal Trial, which is supported by Medtronic. Dr Starnes reported no conflicts of interest.

The Journal policy requires editors and reviewers to disclose conflicts of interest and to decline handling or reviewing manuscripts for which they may have a conflict of interest. The editors and reviewers of this article have no conflicts of interest.

\section{References}

1. Scannell JG. Historical perspectives of the American Association for Thoracic Surgery. Willy Meyer (1858-1932). J Thorac Cardiovasc Surg. 1996; 111:1112.

2. Founding of The American Association for Thoracic Surgery. 50th Anniversary Book. Beverly, MA: American Association for Thoracic Surgery; 1967.

3. Moon MR. In the Words of the Presidents: American Association for Thoracic Surgery. Beverly, MA: American Association for Thoracic Surgery; 2017.

4. Moon MR, Schaff HV, Maloney WT. History of The Journal of Thoracic and Cardiovascular Surgery. J Thorac Cardiovasc Surg. 2017;153:1225-30.

5. Van Allen CM, Jung TS. Postoperative atelectasis and collateral respiration. $J$ Thorac Surg. 1931;1:3-14.

6. AATS 100th Annual Meeting: A virtual learning experience. Available at: https:// www.aats.org/aatsimis/AATSEvent. Accessed May 11, 2020.

7. AATS Virtual Meeting Expo. Available at: https://www.aats.org/aatsimis/ aatsevent/Expo_Hall. Accessed May 11, 2020. 